\title{
A prototype RT-PCR assay for detection of XMRV in multiple human sample types
}

\author{
Ning Tang ${ }^{1 *}$, Andrea Frank ${ }^{1}$, Robert Kowal ${ }^{1}$, Gregor Leckie ${ }^{1}$, John Hackett $\mathrm{Jr}^{2}$, Graham Simmons ${ }^{3}$, Michael Busch³, \\ Klara Abravaya ${ }^{1}$
}

From 15th International Conference on Human Retroviruses: HTLV and Related Viruses

Leuven and Gembloux, Belgium. 5-8 June 2011

\section{Background}

Xenotropic murine leukemia virus-related virus (XMRV) has been reported to be associated with prostate cancer and chronic fatigue syndrome. To help resolve the role of $\mathrm{XMRV}$ in human disease, it is critical to develop sensitive and accurate PCR assays for XMRV detection.

\section{Materials and methods}

The automated m2000 system RT-PCR assays detect the pol and env regions of XMRV in whole blood, plasma, urine, and cell pellets. Assay performance was assessed by testing two blinded panels prepared by the Blood XMRV Scientific Research Working Group (SRWG), as well as clinical specimens.

\section{Results}

For the SRWG whole blood panel, all six XMRV negative samples were assay negative, while all the 22Rv1-spiked samples from 0.5 cells $/ \mathrm{mL}$ to 9,900 cells $/ \mathrm{mL}$ were detected (3/3 for each panel member). For the SRWG plasma panel, all six XMRV negative samples were assay negative, while the $22 R v 1$ supernatant-spiked plasma samples were detected as positive, $1 / 3$ for the $3.2 \mathrm{XMRV}$ copies $/ \mathrm{mL}$ panel member, $2 / 3$ for the 16 copies $/ \mathrm{mL}$ panel member, and $3 / 3$ for panel members containing $>80$ copies $/ \mathrm{mL}$. For screening of clinical specimen, assay positive results were obtained for $10 \%(2 / 20)$ of prostate cancer FFPE specimens, $0.5 \%(2 / 400)$ of prostate cancer urine pellets, and $0 \%(0 / 135)$ of the cervical swab specimens.

\section{Conclusions}

We developed an automated high throughput real-time RT-PCR assay (with internal control) to detect XMRV.

* Correspondence: Ning.Tang@abbott.com

${ }^{1}$ Abbott Molecular Inc., Des Plaines, IL, 60018, USA

Full list of author information is available at the end of the article
Use of this assay should assist in elucidation of the role of XMRV in human disease.

\section{Author details}

${ }^{1}$ Abbott Molecular Inc., Des Plaines, IL, 60018, USA. ${ }^{2}$ Abbott Diagnostics, Abbott Park, North Chicago, Illinois, 60064, USA. ${ }^{3}$ Blood Systems Research Institute, University of California, San Francisco, CA, 94118, USA.

Published: 6 June 2011

doi:10.1186/1742-4690-8-S1-A220

Cite this article as: Tang et al:: A prototype RT-PCR assay for detection of XMRV in multiple human sample types. Retrovirology 2011 8(Suppl 1): A220.
Submit your next manuscript to BioMed Central and take full advantage of:

- Convenient online submission

- Thorough peer review

- No space constraints or color figure charges

- Immediate publication on acceptance

- Inclusion in PubMed, CAS, Scopus and Google Scholar

- Research which is freely available for redistribution
C Biomed Central

\section{() BioMed Central}

(c) 2011 Tang et al; licensee BioMed Central Ltd. This is an open access article distributed under the terms of the Creative Commons Attribution License (http://creativecommons.org/licenses/by/2.0), which permits unrestricted use, distribution, and reproduction in any medium, provided the original work is properly cited. 